\title{
Morphology of flotation froth for enrichment of coal in saline water
}

\author{
Anna Mlynarczykowska ${ }^{1, a}$, Klaudia Tupek ${ }^{1}$, and Konrad Oleksik ${ }^{1}$ \\ ${ }^{1}$ AGH University of Science and Technology, Faculty of Mining and Geoengineering, Department of Environmental \\ Engineering and Mineral Processing, Poland
}

\begin{abstract}
Gas bubbles have an important influence on the efficiency of flotation. The use of mine saline water in coal preparation plants affects the quality of froth. This paper shows the results of morphological analysis of froth generated in flotation enrichment process performed in technological waters with varying degrees of pulp salinity. The raw material model subjected to flotation tests was coal (type 33 in Polish classification). The appearance of froth was registered and evaluated by using a vision system with a special software. The aim of the study was to determine the size and number of air bubbles formed in the presence of inorganic electrolyte ions in the process water as well as their relationship with the efficiency of enrichment process.
\end{abstract}

\section{Introduction}

Flotation is a upgrading method based on physical and chemical differences in surface properties of separated materials [1-2]. In flotation an effective attachment of a particle to a gas bubble occurs due to elementary phenomena that is collision and formation of a stable particle- bubble aggregate [3]. It should be noted that turbulent motions in flotation cell may lead to detachment of particle from a bubble [4-5]. Each aforementioned elementary process has a fundamental impact on the process quality [6].

Gas bubbles play an important role in flotation process as they lift the mineral particles to the pulp surface, forming a froth layer. In the froth zone the raw material is concentrated and separated into useful components and gangue. The froth is a dispersion system [7] which can be formed as a result of either condensation or dispersion of air. In case of froth flotation, it is formed as a result of air dispersion, creating a three-phase system consisting of liquid, gas dispersed in the liquid and solids attached to the gas. Formation of the froth is possible with the presence of surfactants in the pulp which keep the floated particles on the surface, thus giving time to collect them [3-4]. The presence of surfactants in the pulp is the main factor determining formation of a stable froth. They allow to increase the viscosity of solution which reduces liquid leak speed from the froth films (the Plateau theory) and increases the surface flexibility of air bubbles (the Gibbs theory). Nonetheless, it should be noted that the froth stability decreases when an inorganic electrolyte is added to the suspension.

${ }^{\text {a }}$ Corresponding author: mindziu@agh.edu.pl 
The electrolytes reduce the film stability, and thus the stability is also decreased when oval and large particles are present in the suspension [7].

The pulp is aerated in a pneumo-mechanical flotation machine by a rotating agitator placed at its bottom or by feeding compressed air to the cell [8]. Depending on the liquid content in the froth, the froth can be either dry or wet. The best separation of raw material in flotation is achieved at maximum mineralization of air bubbles [4], thus the wet froth is better since it yields more mineral particles. It should also be noted that the upgrading process effectiveness is related to the gaseous phase properties such as size and distribution of formed bubbles as well as volume and concentration of gas flowing through the flotation cell in a unit of time [9]. The probability of floating particles attached to the gas bubbles increases with decreasing bubble size [10]. Consequently, it can be said that the most advantageous degree of pulp aeration occurs at the optimal saturation of the pulp with gas bubbles [10].

The other factor which affects the flotation effectiveness is the type of process water because the flotation pulp contains $80-85 \%$ of water [11]. Water from underground mines is often used in processing plants, and it has a significant concentration of inorganic salts. The stability of formed flotation froth, size of formed air bubbles as well as content of solid phase and water are affected by different physical and chemical properties and hydrodynamic conditions of the process which thus determine the effectiveness of the process [1]. The impact of inorganic electrolytes on the effectiveness of hard coal flotation has been studied for years [12-16]. It is important to understand the influence of salts dissolved in a process water on the flotation results.

One of the elements which allows to effectively control the flotation process is the use of flotation froth image analysis. Traditionally, the flotation process was controlled by operators of flotation machines who controlled the froth existence and stability. However, an effective verification is not easy [18]. There are some papers which provide that the flotation froth image analysis and visualization techniques are effective tools to determine the upgrading efficiency in order to control the industrial processes [18-20]. Banford et al. [19] and Citir et al. [20] verified the possibility of addition a suitable amount of flotation reagent to the hard coal upgrading process by controlling the size and coalescence of air bubbles. On the other hand Jahedsaravani et al. [18] conducted tests to find a relationship between the froth appearance and process efficiency by analysing the images of froth that formed during the coper ore upgrading. The studied parameters included the froth colour, size and velocity of air bubbles. Similar tests were conducted at Divisions of Concentrator of KGHM Polska Miedz S.A. where the dedicated system for technological process control on the basis of froth image analysis was developed and tested. The operation assessment of the visual system used confirmed the improvement of both technological and economical indices at the ore upgrading plant [21-22].

The paper presents the results of flotation processing of hard coal in the presence of process water with varying content of sulfate(VI) ions as well as the analysis of photographs of flotation froth formed during the process. The analysis of images was used to interpret the size and quality of air bubbles in relation to the obtained results.

\section{Materials and methods}

The tests were conducted on class 33 hard coal which was mechanically ground before flotation to obtain the particle size below $0.5 \mathrm{~mm}$. The flotation tests were performed in a Denver pneumaticmechanical laboratory machine with $1 \mathrm{dm}^{3}$ volume. In each flotation test the rotor speed was constant and equal to $1850 \mathrm{rpm}$, while the pulp density was $70 \mathrm{~g} / 1$ [17]. Using the constant rotor speed guaranteed dispersion of air bubbles in the flotation cell, while the low solid content in the pulp allowed to obtain better results [1].

The variable parameter for individual flotations was a degree of pulp salinity expressed as the content of sulfate(VI) ions. The tests were performed on model water solutions of analytical grade sulphuric acid(VI) of various concentrations from 0.063 to $0.5 \mathrm{M}$ [17]. 
The floatation reagent used during the test was an aqueous solution of hexanol with concentration of $2 \mathrm{mM}$ [17]. In flotation hexanol play a role of both frother and collector. Its adsorption on the solidliquid and liquid-gas interfaces increases the coal hydrophobicity and prevents the coalescence of air bubbles in order to form a stable flotation froth as well as reduces a velocity of air bubbles to the froth layer $[1,23]$.

The weighed coal samples were mixed with water for 3 minutes. Then, hexanol was added and mixing continued for another minute to ensure adequate reagent adsorption on the coal surface. After this time the air was introduced to the cell and the flotation process started. The concentrates were collected after 30,30,60,60 and $120 \mathrm{~s}$. The obtained products were dried in a laboratory dryer and weighed in order to determine the yield. However, due to inefficient drying of concentrates caused by increased sorption of sulfates(VI) on the coal surface, the finest fraction below $0.056 \mathrm{~mm}$ had to be sieved and the flotation tests had to be repeated. As a result, the flotation time increased to 6 minutes due to improved upgrading effects. The obtained concentrates and tailings were analysed for the ash content with the Polish Standard PN-ISO 1171: 2002.

For each flotation the digital photographs were taken of the formed froth which morphology changed depending on the concentration of sulfuric(VI) acid in flotation pulp. The experimental set-up is presented in Fig. 1.

The pictures with the best quality were analysed. The bubbles were marked manually. Figure 2 shows the flotation froth before marking the measurement objects, while Fig. 3 shows the same image with bubbles marked for analysis.

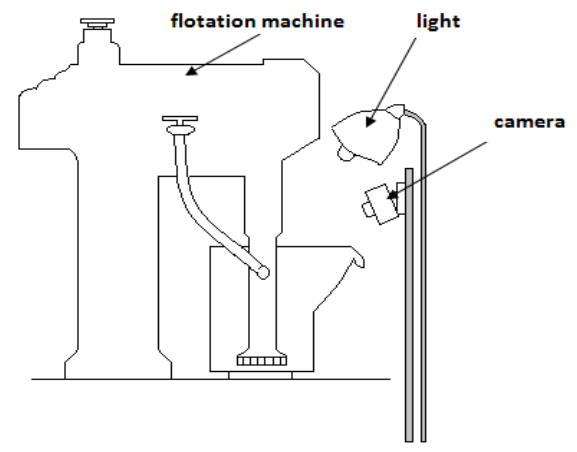

Figure 1. Experimental set-up.

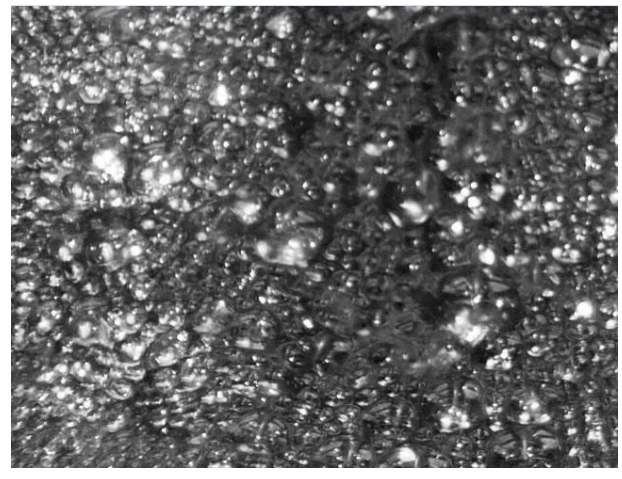

Figure 2. Image of actual flotation froth.

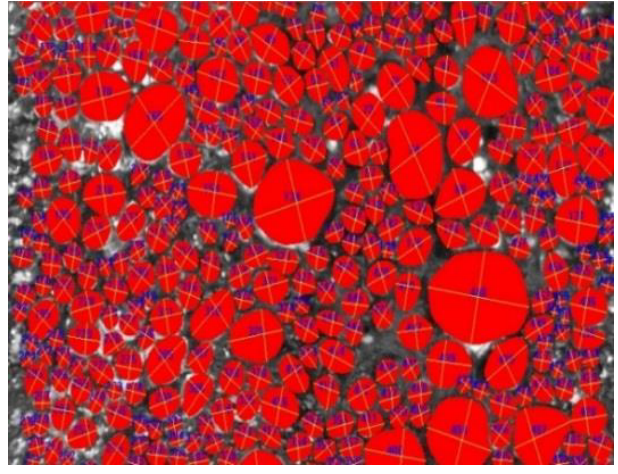

Figure 3. Image of flotation froth with analysis of air bubbles. 


\section{Results}

The analyses allowed to calculate the surface area, perimeter and Feret diameter of individual air bubbles formed during the hard coal upgrading in saline process water. In addition, the software generated statistics for three above-mentioned parameters: mean, standard deviation, standard error, 95 and 99\% confidence intervals, and maximum and minimum values of each parameter. Tables 1 and 2 present results for successive flotation with different pulp salinities. Figures 4-8 show the softwareprocessed images of the selected fragment of the froth photograph on which the individual air bubbles were analysed.

The obtained data were used to plot the Feret diameter histograms (Figs. 9-13.) of air bubbles from individual flotation tests along with the selected match of probability distribution. Tables 3-4 present selected coal upgrading parameters from individual flotation tests.

Table 1. Measurements air bubbles for flotation with 0.125 and $0.063 \mathrm{M} \mathrm{H}_{2} \mathrm{SO}_{4}$.

\begin{tabular}{|c|c|c|c|c|c|c|}
\hline & \multicolumn{3}{|c|}{$\begin{array}{c}\text { salinity of the water } \\
0.063 \mathrm{M} \mathrm{H}_{2} \mathrm{SO}_{4}\end{array}$} & \multicolumn{3}{|c|}{$\begin{array}{c}\text { salinity of the water } \\
0.125 \mathrm{M} \mathrm{H}_{2} \mathrm{SO}_{4}\end{array}$} \\
\hline & $\begin{array}{c}\text { Surface } \\
\text { area } \\
\left.\text { [pixel }^{2}\right]\end{array}$ & $\begin{array}{c}\text { Ferets } \\
\text { diameter } \\
\text { [pixel] }\end{array}$ & $\begin{array}{l}\text { Perimeter } \\
\text { [pixel] }\end{array}$ & $\begin{array}{c}\text { Surface } \\
\text { area } \\
{\left[\text { pixel }^{2}\right]}\end{array}$ & $\begin{array}{c}\text { Feret } \\
\text { diameter } \\
\text { [pixel] }\end{array}$ & $\begin{array}{l}\text { Perimeter } \\
\text { [pixel] }\end{array}$ \\
\hline Mean value & 947.58 & 108.86 & 32.23 & 932.97 & 106.25 & 31.4 \\
\hline $\begin{array}{l}\text { Standard } \\
\text { deviation }\end{array}$ & 941.09 & 43.876 & 12.97 & 1108.99 & 48.22 & 14.22 \\
\hline $\begin{array}{c}\text { Standard } \\
\text { error }\end{array}$ & 42.65 & 1.988 & 0.588 & 51.15 & 2.224 & 0.656 \\
\hline $\begin{array}{l}\text { 95\% confidence } \\
\text { interval }\end{array}$ & 83.79 & 3.907 & 1.154 & 100.52 & 4.371 & 1.289 \\
\hline $\begin{array}{c}99 \% \text { confidence } \\
\text { interval }\end{array}$ & 110.29 & 5.14 & 1.519 & 132.311 & 5.753 & 1.697 \\
\hline $\begin{array}{c}\text { Measurements } \\
\text { number }\end{array}$ & 487 & 487 & 487 & 470 & 470 & 470 \\
\hline Min. & 94.0 & 39.79 & 10.94 & 78.0 & 34.042 & 9.97 \\
\hline Max. & 9395.0 & 372.38 & 109.37 & 11923.0 & 419.75 & 123.21 \\
\hline
\end{tabular}

Table 2. Measurements air bubbles for flotation with $0.125,0.375$ and $0.5 \mathrm{M} \mathrm{H}_{2} \mathrm{SO}_{4}$.

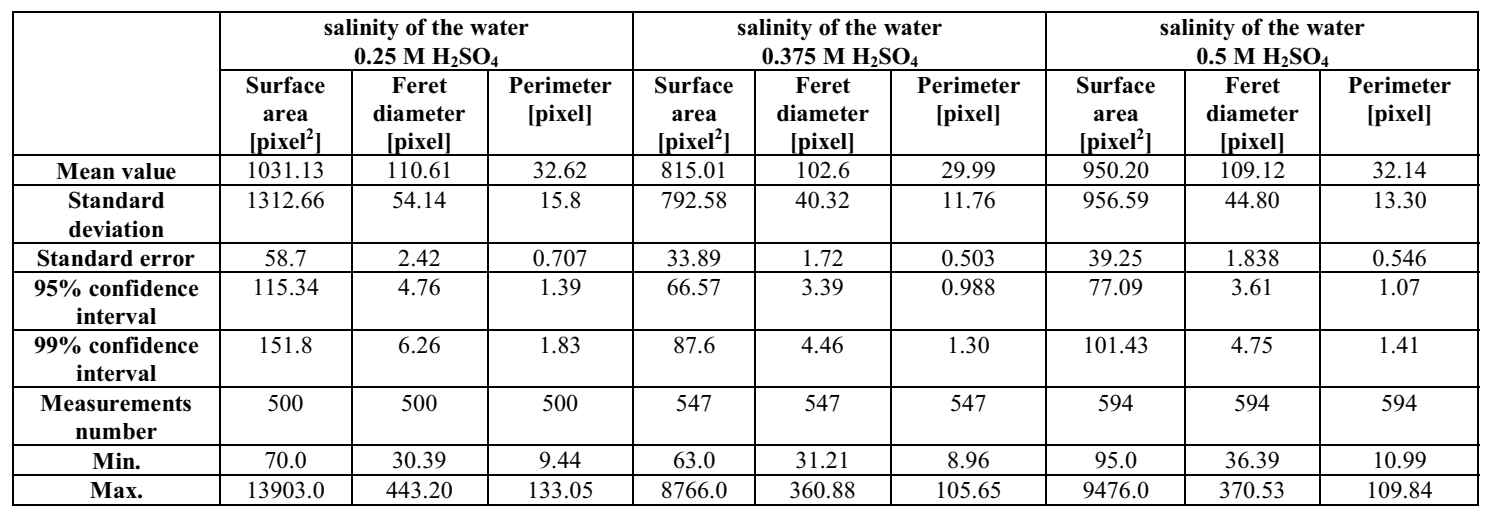




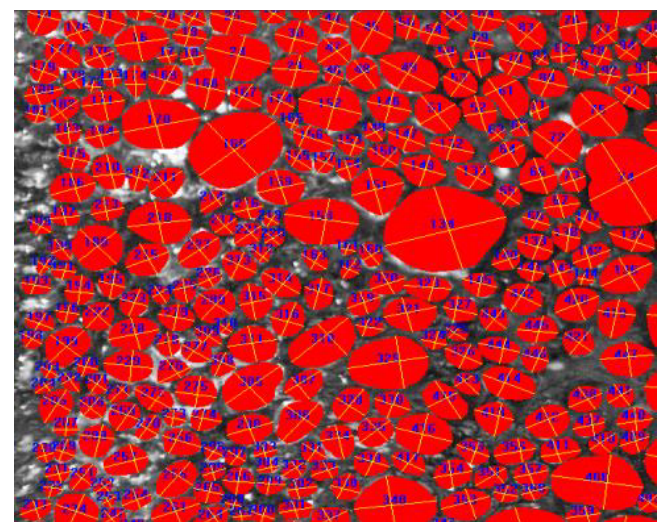

Figure 4. An image of the marked air bubbles for flotation with $0.063 \mathrm{M} \mathrm{H}_{2} \mathrm{SO}_{4}$.

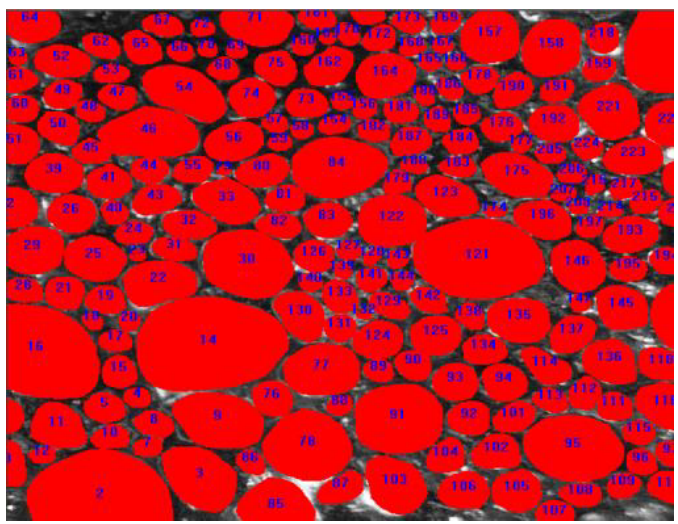

Figure 6. An image of the marked air bubbles for flotation with $0.25 \mathrm{M} \mathrm{H}_{2} \mathrm{SO}_{4}$.

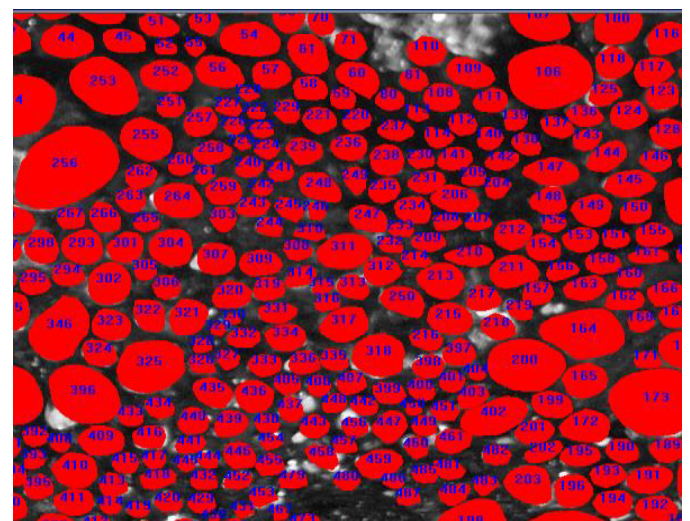

Figure 5. An image of the marked air bubbles for flotation with $0.125 \mathrm{M} \mathrm{H}_{2} \mathrm{SO}_{4}$.

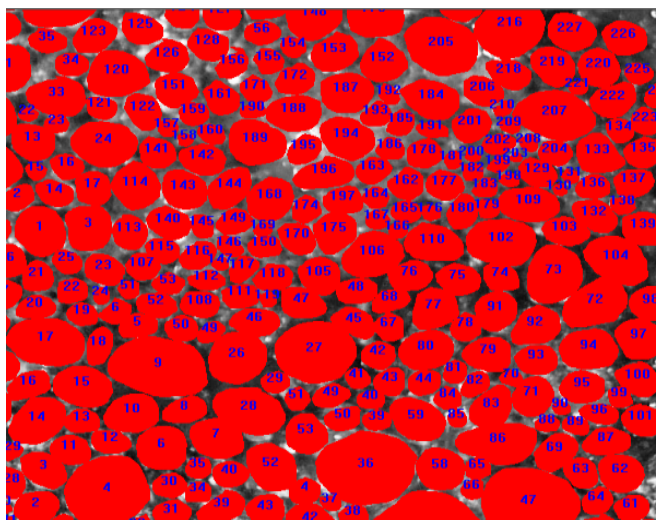

Figure 7. An image of the marked air bubbles for flotation with $0.375 \mathrm{M} \mathrm{H}_{2} \mathrm{SO}_{4}$.

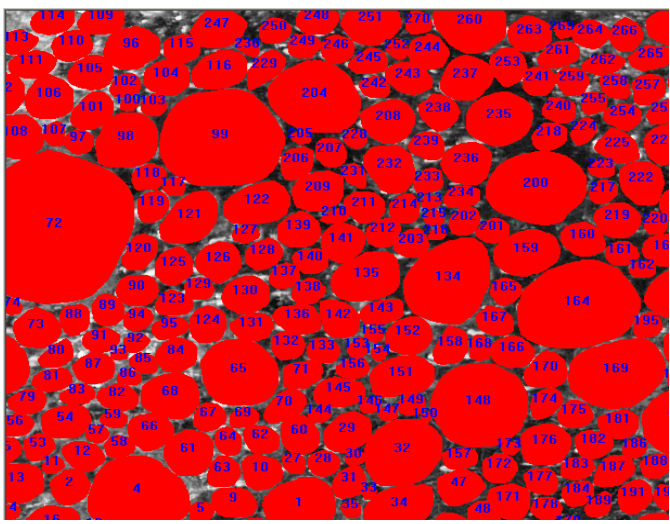

Figure 8. An image of the marked air bubbles for flotation with $0.5 \mathrm{M} \mathrm{H}_{2} \mathrm{SO}_{4}$. 


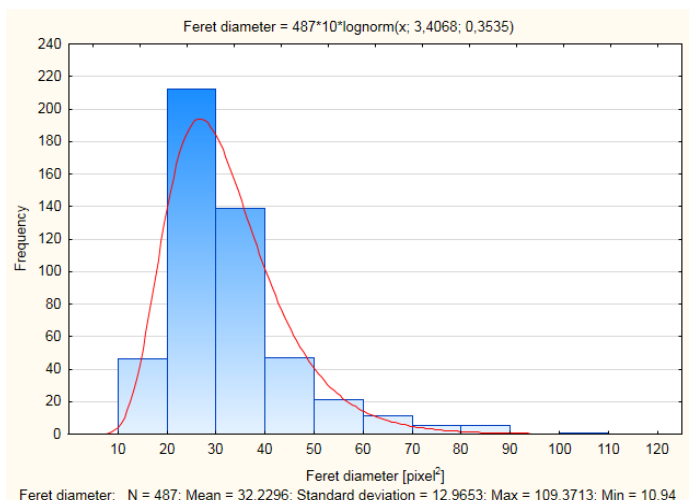

Figure 9. Histogram of Feret diameters for air bubbles together with the adjustment of the lognormal probability distribution for flotation with $0.063 \mathrm{M} \mathrm{H}_{2} \mathrm{SO}_{4}$.

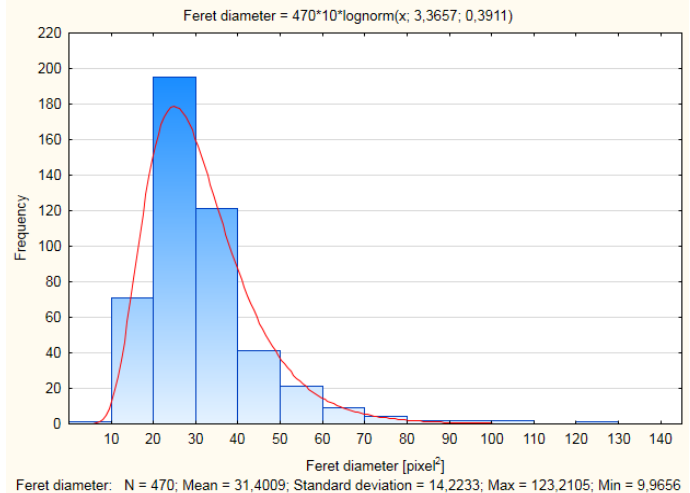

Figure 10. Histogram of Feret diameters for air bubbles together with the adjustment of the lognormal probability distribution for flotation with $0.125 \mathrm{M} \mathrm{H}_{2} \mathrm{SO}_{4}$.

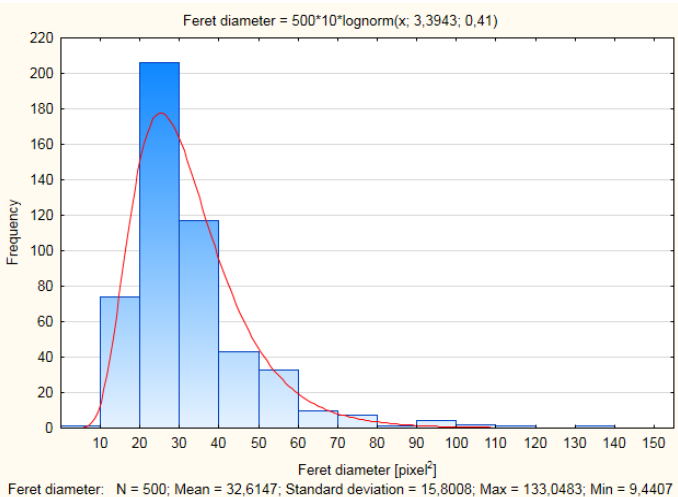

Figure 11. Histogram of Feret diameters for air bubbles together with the adjustment of the lognormal probability distribution for flotation with $0.25 \mathrm{M} \mathrm{H}_{2} \mathrm{SO}_{4}$.

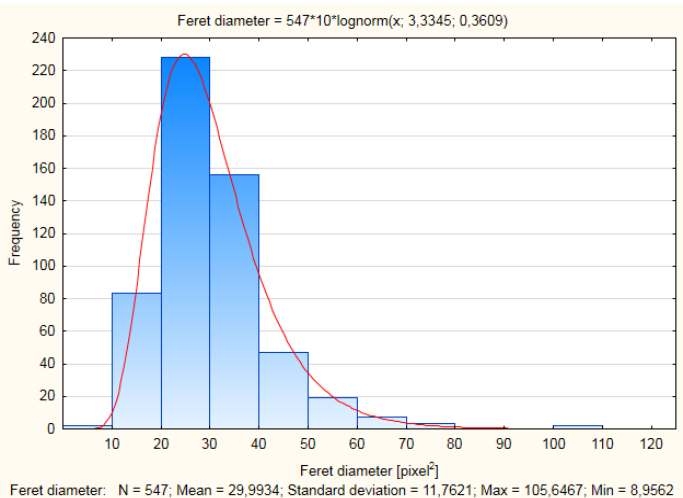

Figure 12. Histogram of Feret diameters for air bubbles together with the adjustment of the lognormal probability distribution for flotation with $0.375 \mathrm{M} \mathrm{H}_{2} \mathrm{SO}_{4}$.

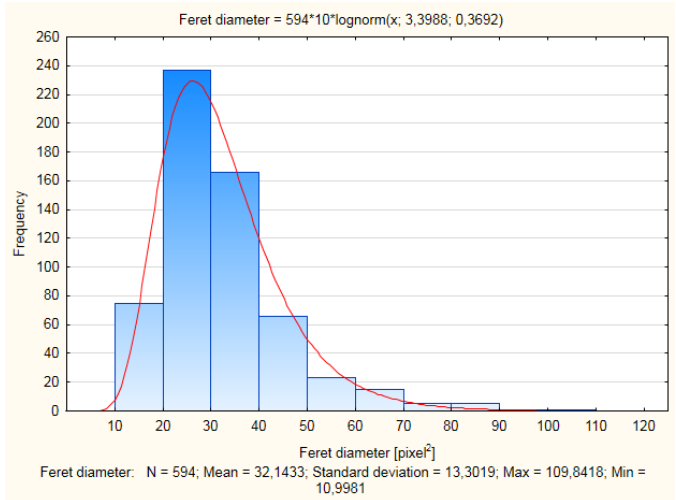

Figure 13. Histogram of Feret diameters for air bubbles together with the adjustment of the log-normal probability distribution for the flotation with $0.5 \mathrm{M} \mathrm{H}_{2} \mathrm{SO}_{4}$. 
Table 3. Selected parameters of coal flotation in the presence of 0.063 and $0.125 \mathrm{M} \mathrm{H}_{2} \mathrm{SO}_{4}$.

\begin{tabular}{|c|c|c|c|c|c|c|c|}
\hline Products & $\begin{array}{c}\text { Flotation time } \\
\text { t[s] }\end{array}$ & \multicolumn{3}{|c|}{$\mathbf{H}_{\mathbf{2}} \mathbf{S O}_{\mathbf{4}} \mathbf{0 . 0 6 3 M}$} & \multicolumn{3}{|c|}{$\mathbf{H}_{\mathbf{2}} \mathbf{S O}_{\mathbf{4}} \mathbf{0 . 1 2 5 M}$} \\
\cline { 3 - 8 } & & yield [\%] & grade[\%] & recovery[\%] & yield [\%] & grade [\%] & recovery [\%] \\
\hline & 0 & & 0.00 & 0.00 & & 0.00 & 0.00 \\
\hline K1 & 30 & 31.51 & 4.52 & 32.51 & 35.90 & 4.63 & 36.81 \\
\hline K2 & 60 & 16.44 & 4.65 & 49.41 & 12.82 & 4.73 & 49.90 \\
\hline K3 & 120 & 13.70 & 5.01 & 63.29 & 12.82 & 4.86 & 62.94 \\
\hline K4 & 180 & 5.48 & 5.15 & 68.81 & 7.69 & 4.98 & 70.72 \\
\hline K5 & 300 & 8.22 & 5.38 & 77.06 & 7.69 & 5.05 & 78.51 \\
\hline tailing & - & 24.66 & 7.48 & 100.00 & 23.08 & 6.98 & 100.00 \\
\hline
\end{tabular}

Table 4. Selected parameters of coal flotation for $0.25,0.375$ and $0.5 \mathrm{M}$ of $\mathrm{H}_{2} \mathrm{SO}_{4}$.

\begin{tabular}{|c|c|c|c|c|c|c|c|c|c|c|}
\hline \multirow[t]{2}{*}{ Products } & \multirow{2}{*}{$\begin{array}{c}\text { Flotation } \\
\text { time } \\
t[s]\end{array}$} & \multicolumn{3}{|c|}{$\mathrm{H}_{2} \mathrm{SO}_{4}-0.25 \mathrm{M}$} & \multicolumn{3}{|c|}{$\mathrm{H}_{2} \mathrm{SO}_{4}-0.375 \mathrm{M}$} & \multicolumn{3}{|c|}{$\mathrm{H}_{2} \mathrm{SO}_{4}-0.5 \mathrm{M}$} \\
\hline & & $\begin{array}{c}\text { yield } \\
{[\%]}\end{array}$ & $\operatorname{grade}[\%]$ & recovery [\%] & $\begin{array}{c}\text { yield } \\
{[\%]}\end{array}$ & $\begin{array}{c}\text { grade } \\
{[\%]}\end{array}$ & $\begin{array}{c}\text { recovery } \\
{[\%]}\end{array}$ & $\begin{array}{c}\text { yield } \\
{[\%]}\end{array}$ & $\begin{array}{c}\text { grade } \\
{[\%]}\end{array}$ & $\begin{array}{c}\text { recovery } \\
{[\%]}\end{array}$ \\
\hline & 0 & & 0.00 & 0.00 & & 0.00 & 0.00 & & 0.00 & 0.00 \\
\hline K1 & 30 & 21.05 & 3.15 & 21.59 & 20.51 & 3.05 & 21.01 & 30.43 & 2.76 & 31.10 \\
\hline $\mathrm{K} 2$ & 60 & 15.79 & 1.96 & 38.25 & 10.26 & 3.00 & 31.53 & 13.04 & 2.59 & 44.50 \\
\hline K3 & 120 & 13.16 & 2.29 & 51.74 & 12.82 & 2.95 & 44.69 & 10.87 & 2.64 & 55.60 \\
\hline $\mathrm{K} 4$ & 180 & 7.89 & 2.46 & 59.81 & 5.13 & 2.96 & 49.95 & 4.35 & 2.61 & 60.07 \\
\hline $\mathrm{K} 5$ & 300 & 7.89 & 2.56 & 67.89 & 10.26 & 3.04 & 60.42 & 6.52 & 2.65 & 66.72 \\
\hline K6 & 360 & 7.89 & 2.66 & 75.96 & 7.69 & 3.02 & 68.31 & 4.35 & 2.66 & 71.15 \\
\hline tailing & - & 26.32 & 5.58 & 100.00 & 33.33 & 5.35 & 100.00 & 30.43 & 4.83 & 100.00 \\
\hline
\end{tabular}

The analysis of experimental results shown in Tables 3-4 indicated that the most advantageous effectiveness of hard coal flotation was achieved when the concentration of $\mathrm{H}_{2} \mathrm{SO}_{4}$ was $0.25 \mathrm{M}$, and the tests proved that both high and low concentrations of $\mathrm{H}_{2} \mathrm{SO}_{4}$ in process water reduce the upgrading effectiveness. In the case of low concentration, the impact of ions concentrations on the obtained concentrate yields can be caused by an increased particles surface charge which reduces the wetting angle, and thus decreases the flotation capability of mineral particles [3, 15]. Higher concentrations, on the other hand, can increase the coal particle hydration, thus worsening the upgrading results [7].

The morphological analysis of concentrates photographs for individual fraction flotation and yields of individual concentrates presented in Tables 3-4 also indicate that more than half of coal particles were lifted to the flotation froth during the first minute of the process. In addition, with flotation time and increased concentration of $\mathrm{H}_{2} \mathrm{SO}_{4}$ in a model process water, the number of particles floating to the froth slightly decreased. This finally led to smaller coal yields at higher concentrations of inorganic electrolyte. Moreover, it was observed that flotation with inorganic electrolyte ions caused increased dispersion of air bubbles in the flotation cell, leading at the same time to formation of stable and high froth [17]. Smaller gas bubbles caused the reduced probabilities of collision and adhesion, while the larger gas bubble sizes increased the probability of particle-air bubble aggregates being lifted to the flotation froth [24].

The results of image analysis presented in the form of histograms (Figs. 9-13) indicated that with increasing concentration of sulfate(VI) ions in the process water, the number of bubble in the flotation cell increased from 487 to almost 600 with the exception of flotation with $0.125 \mathrm{M}$ salinity where the number of counted air bubbles was 470 . In addition, the statistical data suggested that the greatest mean Feret diameter was achieved for $0.25 \mathrm{M}$ concentration of sulfate(VI) ions, and the smallest for $0.375 \mathrm{M}$. Taking into account the diversity of air bubbles, the biggest ones can be observed at $0.25 \mathrm{M}$ process water salinity as shown by the obtained standard deviation values.

The amount of water in froth for three greatest concentrations of sulfate(VI) ions in process water was tested as an additional element. The reason for studying the water amount in obtained products and its impact on the flotation results was an ineffective drying of concentrates for these tests which was caused by increased sorption of sulfates on the coal surface. This was the reason for retesting after 
sieving the coal particles below $0.056 \mathrm{~mm}$. During the retests, the wet froth products were weighed before drying and the amount water in the flotation froth was determined. The results are presented in Figs. 14-16.

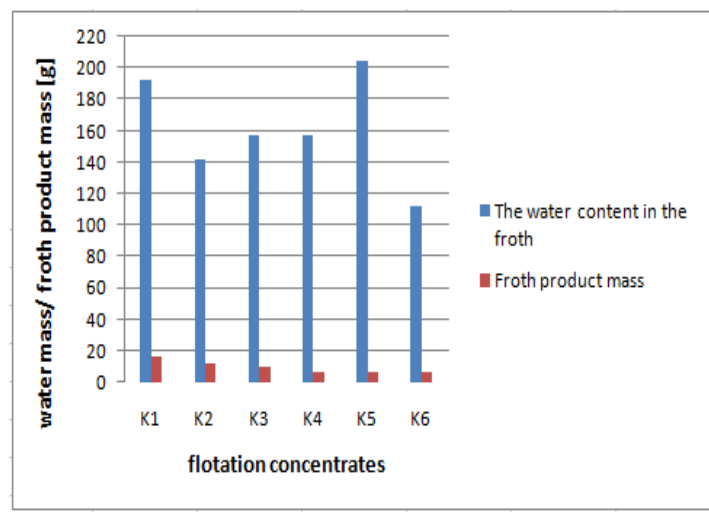

Figure 14. Water and solids yield after flotation with $0.25 \mathrm{M} \mathrm{H}_{2} \mathrm{SO}_{4}$.

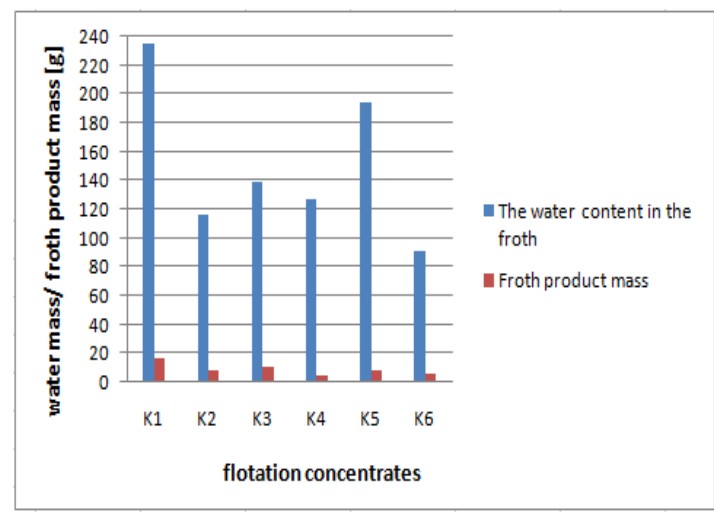

Figure 15. Water and solids yield after flotation with $0.375 \mathrm{M} \mathrm{H}_{2} \mathrm{SO}_{4}$.

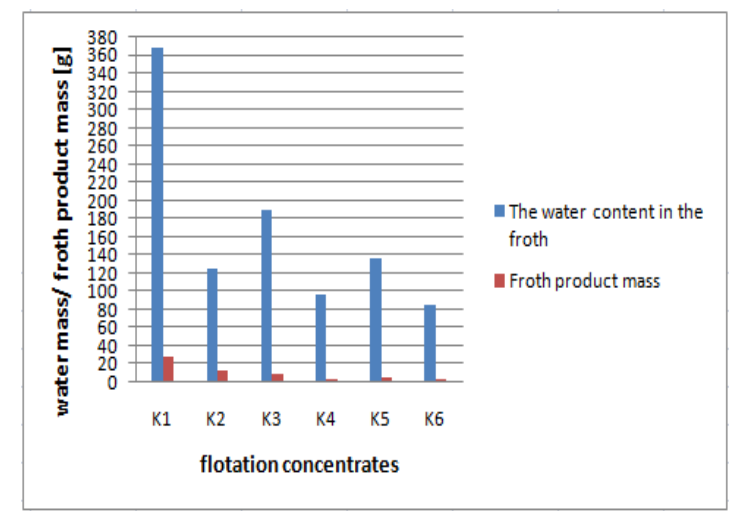

Figure 16. Water and solids yield after flotation with $0.50 \mathrm{M} \mathrm{H}_{2} \mathrm{SO}_{4}$.

Figures 14-16 shows that with increased concentration of sulfuric(VI) acid in process water, in case of the first concentrate, the amount of water in the froth product increased, but it decreased in concentrates $4-6$. Simultaneously, in case of all three flotation tests a similar tendency was observed as the flotation time increased. In all flotation tests, the largest amount of water in the froth was obtained in the first 30 seconds of the process when the largest weight of the froth product was obtained. This is linked to water being lifted in the form of thin layers which prolonged both the bubbles and the particles attached to them [25]. Thus, in the last concentrates the water content was the smallest because the product weight was the lowest. Hence, it can be said that the amount of raw material floated to the concentrate depends on the water content in the froth, which is associated with the effectiveness of flotation process. It is believed that similar relationships took place also in case of two lowest salt concentrations in the process water.

\section{Summary}

As the hard coal processing takes place in water from underground mines, which contains a significant amount of inorganic salts, it is important to study the impact of inorganic electrolytes on the flotation 
process. Therefore, the presented in this work tests were related to the impact of process water salinity on the size and number of formed air bubbles in the froth and on the upgrading performance. Based on the results the following conclusions can be drawn.

1. The increased presence of inorganic electrolyte ions in a process water resulted in increased dispersion of air bubbles in the flotation cell.

2. The more wet the flotation froth, the larger amounts of froth products were obtained.

3. The greatest mean Feret diameter was achieved for $0.25 \mathrm{M}$ concentration of sulfuric acid(VI) where the technological results were the best, and the smallest mean Feret diameter was achieved for $0.375 \mathrm{M}$ sulfuric acid(VI) where the flotation results were the worst.

4. The greater the diversity of air bubble size determined on the basis of standard deviation, the more effective the flotation process.

\section{References}

1. A. Grabiec, A. Młynarczykowska, in Proccedings of Conference of Young Researches ProFuturo (2014)

2. Z. Blaschke, M. Brożek, E. Mokrzycki, Z. Ociepa, T. Tumidajski, Mining. częśc $V$ (Wydawnictwo „AGH”, Kraków, 1981)

3. J. Drzymała, Podstawy mineralurgii, 2nd ed. (Oficyna Wydawnicza PWR, 2009)

4. S. Blaschke, Przeróbka mechaniczna kopalin część II (Wydawnictwo Śląsk, Katowice, 1984)

5. M. Brożek, A. Młynarczykowska, Physicochem. Probl. Miner. Process. 44, 23 (2010)

6. A. Młynarczykowska, A. Turno, Prace Naukowe Instytutu Górnictwa PWR, 103, 211 (2003)

7. E. Małysa, Z. Ociepa, E. Oruba, S. Sanak-Rydlewska, Ćwiczenia laboratoryjne z flotacji, 2nd edn. (Wydawnictwo „AGH”, Kraków, 1981)

8. A. Nyrek, K. Oleksik, BSc thesis, (2014)

9. A. Młynarczykowska, A. Nyrek, K. Oleksik, IM, Jan.-June, 181 (2015)

10. S. Blaschke, Procesy technologiczne w przeróbce kopalin użytecznych (Wydawnictwo „AGH”, Kraków, 1987)

11. E. Muzenda E., Int. J. Chem., Mol., Nucl. Mater. Metall. Eng., 4(9), 562 (2010)

12. R.H. Yoon, Min. Cong. J., 68, 76 (1982)

13. R.H. Yoon, J.B. Sabey, Interfacial Phenomena in Coal Technology, (Marcel Dekker, New York, 87, 1989).

14. J.S. Laskowski, Coal Flotation and Fine Coal Utilisation (Elsevier, Amsterdam, 2001)

15. J. Drzymała, T. Ratajczak, Flotacja solna (Oficyna Wydawnicza PWR, Wrocław, 2003)

16. O. Ozdemir, Physicochem. Probl. Miner. Process. 49(2), 511 (2013)

17. K. Tupek, $M S c$ thesis, (2015)

18. A. Jahedsaravani, M.H. Marhaban, M. Massinaei, Miner. Eng. 69, 137 (2014)

19. AW. Banford, Z. Aktas, E.T. Woodburn, Powder Techno. 98(1), 61 (1998)

20. C. Citir, Z. Aktas, R. Berber, Comput. Chem. Eng. 28(5), 625 (2004)

21. A. Konieczny, W. Pawlos, M. Jach, R. Pępkowski, M. Krzemińska, R. Kaleta, D. Foszcz, Min. Geol. 6(2), 61 (2011)

22. E. Małysa, A. Iwańska, Min. Geol, 34(4/1), 165 (2010)

23. D. Tao, Sep. Sci. Technol. 39(4), 741 (2004)

24. E. Małysa, A. Surowiak, Miner. Resour. Manag.t 24(4/1), 53 (2008) 